\title{
PENERAPAN CARBON OFFSET POLICY SEBAGAI BAGIAN DARI CSR PERUSAHAAN MELALUI CARBON ACCOUNTING
}

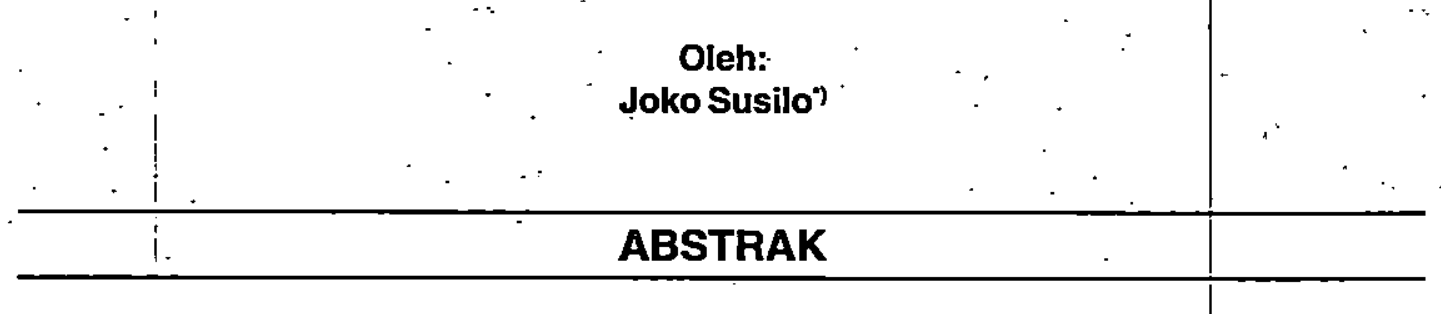

Artikel ini bertujuan untuk menjelaskan peran aküntansi di dalam mengatasi isu pemanasan global sesuai tingkatan kapasitasnya. Pembahasan dimulai dari teori bahwa akuntansi tidak bebas nilai (value laden) sehingga dengan adanya green movement maka muncul istilah green accounting atau akuntansi lingkungan. Terkait dengan isu pemanasan global yang diakibatkan emisi karbon (GHG); maka muncullah carbon accounting. Carbon accounting mengukur totnl emisi gas rumah kaca yang disébabkan secara langsung dan tidak langsung oleh seorang indioidu, aktivitas, organisasi itau produk. Penildian karbon dan pelaporannya ini dapat membantu organisasi mengadopsi strategi yang bertujuan untuk mengatasi perubahan iklim. Salah satu manfaat dari carbon accounting ini adalah dapat diterapkannya kebijakan carbon offset perusahaan berupa penanaman pohon sesuai dengan emisi karbon yang dihasilkannya sebagai salah satu bentuk pertanggungjawaban sosial dan lingkungan oleh perusahaan.

1. PENDAHULUAN

Global warming adalah isu lingkungan terpenting sekarang. Daniel Esty danAndrew Winston dalam Green to Gold membuat peringkat 10 isu lingkungan paling berpengaruh terhadap bisnis, dan perubahan iklim yang disebabkan oleh pemanasan global menempati urutan teratas. Berbeda dengan kebanyakan isu lingkungan yang bersifat lokal, pemanasan global ini akan mengenai-dan berasal dari-setiap orang. Setidaknya, dalam dua abad terakhir, berbagai. aktivitas manusia diyakini mempercepat munculnya dampak pemanasan global. Industrialiasi, penggunaan kendaraan bermotor, pemenuhan kebutuhan energi rumah tangga, yang semuanya sulit dilepaskan dari bahan bakar fosil, serta kegiatan lain yang berhubungan dengan penggundulan hutan ialah sejumlah aktivitas yang menghasilkan gas karbondioksida, lalu terakumulasi menjadi gas rumah kaca. Indoṇesia sendiri, menurut model yang dikembangkan $\mathrm{Dr}$. Armi Susandi, MT dari ITB akan mengalami penambahan suhu sebesar 3 hingga 3,5 derajat Celsius pada tahun 2100 dibandingkan suhu pada tahuin 1990 (Jalal, 2007).

*) Joko Susilo adalah Staff Pengajar Fakultas Ekonomi - Úniversitas Islam Indonesia: 
Akuntansi merupakan wacana yang dipengaruhi dan mempengaruhi lingkungannya. Akuntanși tumbuh dan berkembang di dalam masyarakat yang juga terus berkembang. Eksistensinya tidak bebas nilai terhadap perkembangan masa. Metode-metode pembukuan yang dikenalkan oleh Luca Pacioli pada waktu itu dipandang sudah mencukupi dan memadai lantaran mampu memecahkan masalah pelaporan dán pembukuan bisnis yang diperlukan pada masa tersebut, namun ketika kompleksitas bisnis semakin tinggi, diperlukan metode-metode pengukuran, pengakuan dan pelaporan yang lebih advanced (Utomo, 2001). Alhasil, akuntansi terus berkembang menyesuaikan kebutuhan zamannya.

Manakala gerakan peduli lingkungan (green movement) melanda dunia, akuntansi berbenah diri agar siap menginternalisasi berbagai eksternalitas yang muncul sebagai konsekuensi proses industri, sehingga lahir istilah green accounting atau akuntansi lingkungan (environmental accounting). Demikian pula waktu sebagian industri mulai menunjukkan, wajah sosialnya (capitalism with human face), yang ditunjukkan dengan perhatian pada employees dan aktivitasaktivitas community development, serta perhatian pada stakeholders lain, akuntansi mengakomodasi perubahan tersebut dengan memunculkan wacana akuntansi sosial (sosial responsibilty accounting). Sejak memahami akuntansi sebagai bagian dari fungsi service baik sosial, budaya, ekonomi bahkan politik, maka banyak faktor mempengaruhi akuntansi itu sendiri. Belkoui dan Ronald (1991) menjelaskan bahwa budaya merupakan faktor utama yang mempengaruhi perkembangan struktur bisnis dan lingkungan sosial, yang pada akhirnya akan mempengaruhi akuntansi.

- Akuntansi lingkungan kerapkali dikelompokkan dalam wacana akuntansi sosial. Hal ini terjadi karena kedua diskursus tersebut memiliki tujuan yang sama, yaitu menginternalisasi eksternalitas (lingkungan sosial dan lingkungan ekologis), baik positif maupun negatif, ke dalam laporan keuangan perusahaan. Serupa dengan akuntansi sosial, akuntansi lingkungan juga menemui kesulitan dalam pengukuran nilai cost and benefit eksternalitas yang muncul dari proses industri. Bukan hal yang mudah untuk mengukur kerugian yang diterima masyarakat sekitar dan lingkungan ekologis yang ditimbulkan polusi udara, limbah cair, kebocoran tabung amoniak, kebocoran tabung nuklir atau eksternalitas lain. Banyak cara yang dapat dilakukan oleh perusahaan untuk mengkomunikasikan perhatian mereka terhadap permasalahan lingkungan hidup ini, meliputi surat kabar, publikasi bisnis, televisi dan atau radio, serta laporan keuangan tahunan (Gamble et al., 1995).

Saat ini tidak ada standar yang baku mengenai item-item pengungkapan lingkungan. Namun, beberapa institusi telah mengeluarkan rekomendasi pengungkapan lingkungan, antara lain Dewan Ekonomi dan Sosial - Perserikatan Bangsa-Bangsa (ECOSOC-PBB), Ernst and Ernst, Institute of Chartered ACcountant in England and Wales (ICAEW) dan Global Reporting Initiative (GRI). Motivasi yang melatarbelakangi perusahaan untuk melaporkan permasalahan lingkungan lebih didominasi oleh faktor kesukarelaan (Ball, 2005; Choi, 1999), 
Joko Susilo: Penerapan Carbon Offset Policysebagai Bagian dari CSR Perusahaan ...

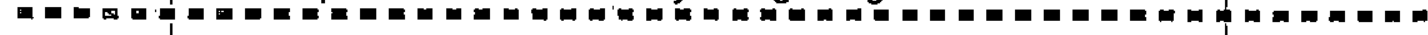

kapitalisasi atau pembiayaan dari permasalahan lingkungan serta adanya kewajiban bersyarat yang diatur dalam standard akuntansi seperti FASB (Gamble et al., 1995), adanya teori keagenan (Watts danZimmerman's, 1978), teori legitimasi dan teori ekonomi politik (Gray et al., 1995).

3. CARBON ACCOUNTING

Carbon Accounting merupakan bagian dari akuntansi lingkungan yang menginformasikan kepada pengguna laporan keuangan terkait dengan emisi karbon dioksida yang diakibatkan dari operasional kegiatannya. Carbon accounting adalah akuntansi yang dilakukan untuk mengukur jumlah karbon dioksida yang tidak akan dilepaskan ke udara sebagai hasil dari mekanisme fleksible organisisasi sebagai wujud kepatuhan organisasi terhadap perjanjian Kyoto. Istilah lain yang dikenal adalah Enterprise Carbon Accounting, yakni suatu proses akuntansi yang bertujuan untuk mempercepat dan menghemat biaya di dalam usahanya mengumpulkan, meringkas, dan melaporkan perusahaan dan rantai persediaan Greenhouse Gases. Jadi carbon accounting ini mengukur total emisi gas rumah kaca yang disebabkan secara langsung dan tidak langsung oleh seorang individu, aktivitas, organisasilatau produk. Penilaian karbon dan pelaporannya ini dapat membantu organisasi mengadopsi strategi yang bertujuan untuk memerangi perubahan iklim. Laporan emisi karbon dioksida ataupun pencemaran udara bentuk lainnya ini dilaporkan dalam laporan keuangannya baik dalam bentuk yang paling sederhana (footnote), short qualitative description ataupun extended qualitative-quantitative description. Tujuan dari akuntansi karbon ini adalah sebagai masukan bagi para penentu kebijakan terkait dengan pengelolaan pencemaran udara yang dihasilkan tersebut. Keberadaan carbon accounting ini menjadi sangat penting manakala isu pemanasan global semakin hari semakin ramai didiskusikan. Informasi yang dihasilkan dari akuntansi karbon dan pelaporannya kini menjadi suatu kebutuhan yang mampu mengendalikan perusahaan di dalam menghasilkan emisi karbon dioksida.

\section{PENCEMARAN UDARA-EMISI KARBON DIOKSIA}

Pencemaran udara ialah jika udara di atmosfer dicampuri dengan zat atau radiasi yang berpengaruh jelek terhadap organisme hidup. Jumlah pengotoran ini cukup banyak sehingga tidak dapat diabsorpsi atau dihilangkan. Umumnya pengotoran ini bersifat alamiah, misalnya gas pembusukan, debu akibat erosi, dan serbuk tepung sari yang terbawa angin, kemudian ditambah olehi manusia karena ulah hidupnya dan jumlah serta kadar bahayanya semakin mëningkat. Pencemar udara dapat digolongkan kedalam tiga kategori, yaitu (1) pergesekan permukaan; (2) penguapan; (3) pembakaran; (Sastrawijaya, 2000). Gas buang sisa pembakaran bahan bakar minyak mengandung bahanbahan pencemar seperti sulfur dioksida (SO2), nitrogen oksida (NOx), karbon monoksida (CO), volatile hydrocarbon (VHC), suspended particulate matter dan partikel lainnya. Bahan-bahan pencemar tersebut dapat berdampak negative terhadap manusia 
ataupun ekosistem bila melebihi konsentrasi tertentu. Peningkatan penggunaan bahan bakar minyak untuk sektor transportasi menyebabkan gas buang yang mengandung polutan juga akan naik dan akan mempertinggi kadar pencemaran udara (Sugiyono, 1998).

Sebagaimana yang banyak ditulișkan, dari empat penyebab emisi terbesar, tiga di antaranya disebabkan oleh aktivitas perusahaan, yaitu dalam pembangkitan energi ( $40 \%)$, industri (17\%) dan transportasi (20\%). Ketiganya konsisten muncul pada perhitungan global maupun Indonesia, hanya urutannya saja yang berbeda. Peringkat berikutnya baru diduduki oleh aktivitas konsumsi oleh rumah tangga (14\%). Peringkat yang berbeda - dan lebih komprehensifditunjukkan oleh data global yang disajikan oleh Stern Review (lihat diagram lingkaran di samping) untuk emisi tahun 2000. Sayangnya laporan tersebut tidak menyediakan data mutakhir.

\section{Gambar 1. Total Emisi Karbon di Indonesia}

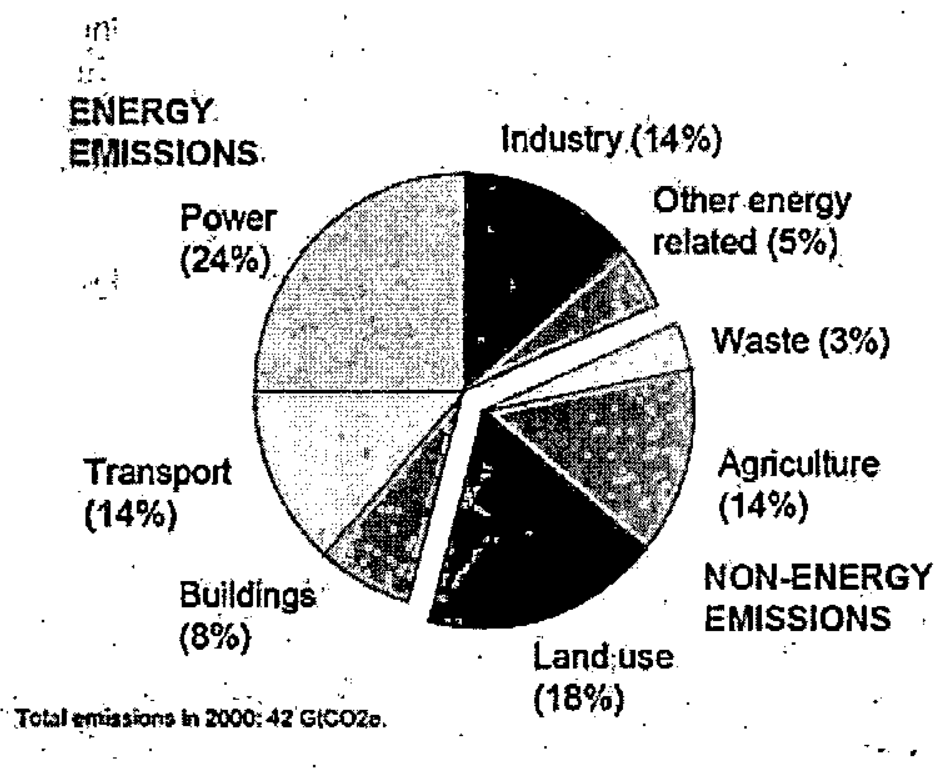

Sumber; Jalal (2007)

Untuk mengetahui seberapa besar emisi karbon dioksida yang dihasilkan dari aktivitas kota, maka dilakukan pendekatan penghitungan emisi karbon dioksida. Faktor emisi adalah nilai yang digunakan untuk mendapatkan berat karbon dioksida berdasarkan besaran-besaran yang dinilai, misalnya konsumsi listrik, minyak tanah, premium, solar dan sebagainya. Faktor emisi untuk perhitungan karbon dioksida dalam penelitian ini diperoleh melalui studi literatur. Faktor emisi disajijkan pada Tabel 2, 3, dan 4. 
Joko Susilo: Penerapan Carbon Offset Policysebagai Bagian dari CSRPerusahaan ...

Tabel 2

Faktor Emisi untuk Bahan Bakar

\begin{tabular}{|c|c|c|}
\hline Bahan Bakar Cair & Gram CO2/gallon. & gram QO2/liter \\
\hline -Bensin & 8,9 & $\therefore \quad 2,3:$ \\
\hline Solar & $=10,1$ & 2,7 \\
\hline
\end{tabular}

Sumber : World Resources Institute (WRI) and World Business Council for Sustainable Development (WBCSD, 2001)

Tabel 3

Faktor untuk Konsumsi Listrik dengan Semua Bahan Bakar

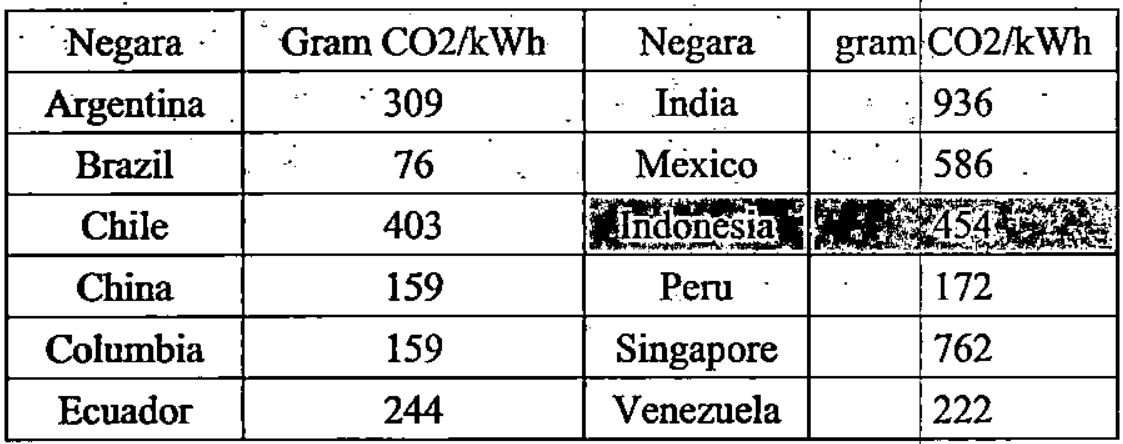

Sumber : World Resources Institute (WRI) and World Business Council for Sustainable Development (WBCSD, 2001)

Tabel 4

Faktor Emisi untuk Menghitung Karbon Dioksida dari Konsumsi Minyak

\begin{tabular}{|c|c|c|}
\hline Fuel Type & \multicolumn{3}{|c|}{ gram CO2/liter } \\
\hline Natural Gas & 0,19 & \\
\hline Gas/Diesel Oil & 0,25 & \\
\hline Petrol & 0,24 & \\
\hline Heavy Fuel Oil & 0,26 & $\therefore$ \\
\hline Rata-rata & 0,24 & \\
\hline
\end{tabular}

Sumber : World Resources Institute (WRI) and World Business Council for Sustainable Development (WBCSD, 2001) 
CSR atau tanggung jawab sosial perusahaan kini semakin popular. Berbagai peristiwa di tingkat internasional maupun nasional membuktikan bahwa semakin banyak perusahaan yang menerima tanggung jawab yang lebih luas daripada sekadar tanggung jawab menghasilkan profit untuk pemilik modainya. Walau definisi CSR itu beragam, namun konvergensi dengan pembangunan berkelanjutan membuat pengertiannya adalah: upaya sungguh-sungguh dari entitas bisnis untuk meminimumkan dampak negatif dan memaksimumkan dampak positif operasinya terhadap seluruh pemangku kepentingan dalam ranah ekonomi, sosial dan lingkungan untuk mencapai tujuan pembangunan berkelanjutan.

Jadi, bila sebuah perusahaan ingin dinyatakan sebagai perusahaan yang bertanggung jawab, syarat utamanya adalah mengetahui secara persis apa saja dampak dari operasinya, baik negatif maupun positif. Dampak negatif itu kemudian diminimumkan dengan pengelolaan, dan apabila tidak bisa menjadi nol maka harus ada upaya mengkompensasi itu, sementara dampak positifnya dimaksimumkan. Kalau hal ini diterjemahkan ke dalam isu pemanasan global, maka perusahaan yang bertanggung jawab haruslah menghitung dengan presisi tinggi emisi karbonnya. Tujuan tertinggi adalah membuat sebuah proses produksi yang netral karbon. Buat perusahaan, jalan utamanya ada dua: carbon offset (mengurangi/mengganti karbon yang telah diemisikan oleh yang bersangkutan) dan penggantian ke teknologi yang lebih ramah atmosfer alias beremisi lebih kecil (nol).

Ada berbagai aktivitas yang termasuk ke dalam carbon offset, yaitu seluruh aktivitas yang bisa mengurangi emisi $\mathrm{CO} 2$ seperti penanaman pohon, penggunaan energi berkelanjutan (air, angin, dsb.), dan efisiensi energi. Seluruh kegiatan tersebut harus diketahui dampak pengurangan emisinya (sudah ada ukuran-ukuran itu, misalnya - seperti yang telah dikemukakan pada bagian sebelumnya-menanam dan memelihara pohon sepanjang daur hidupnya akan menyerap emisi sebanyak 1 ton), sehingga perhitungan antara emisi suatu kegiatan dengan pengurangnya bisa diseimbangkan. Di Eropa perhitungannya sudah lebih maju, karena orang atau perusahaan sudah bisa mengonversi emisi ke dalam uang yang dibayarkan kepada organisasi yang melakukan kegiatankegiatan di atas.

Penanaman pohon buat perusahaan, seperti yang sudah dijelaskan juga merupakan salah satu cara melakukan carbon offset. Perusahaan yang mengetahui persis jumiah emisinya bisa membayar semacam pajak karbon untuk setiap kilogram atau ton emisinya. Ada beberapa lembaga yang bisa menerima itu, dengan berbagai kegiatan yang membuat volume karbon di atmosfer berkurang. Banyak di antaranya yang melakukan penanaman pohon itu. Namun, perușahaan juga bisa melakukannya sendiri, dengan jalan menghitung kewajiban berapa pohon yang harus ditumbuhkannya setelah mengetahui emisinya. Secara kasar, sepanjang daur hidupnya satu pohon bisa mengkonsumsi 1 ton $\mathrm{CO} 2$, walaupun tentu saja ada yang lebih besar dan lebih kecil daripada itu. Sehingga, kalau sebuah perusahaan misalnya mempunyai emisi 10.000 ton karbon setiap 
tahunnya, maka sejumlah 10.000 pohon harus ditanam dan dipelihara untuk membuat proses produksinya netral karbon. Itupun baru dapat dikatakan bahwa perusahaan ítu telah meminimumkan dampak negatifnya, kalau hendak memaksimumkan dampak positifnya, penanaman pohon yang harus dilakukan tentu saja harus melampaui itu. Penanaman pohon sebagai bentuk CSR adalah jalan yang tampaknya akan bisa diterima oleh banyak pihak di Indonesia, mengingat deforestasi membutuhkan upaya penanganan yang serius. (Jalal, 2008)

Berkenaan dengan tempat, yang sangat penting dipertimbangkan adalah apakah ada jaminan bahwa dalam waktu yang cukup lama pohon tersebut bisa hidup dan berfungsi menyerap $\mathrm{CO} 2$, karena kalau hal tersebut tidak dapat dijamin maka sia-sialah seluruh pekerjaan, dan tujuan carbon offset tidak bisa tercapai. Karenanya, menanam di lahan-lahan

yang ditetapkan fungsinya oleh pemerintah sebagai lahan konservasi (taman nasional, cagar alam, suaka margasatwa, dsb.), atau di tempat-tempat yang ditetapkan sebagai taman kota/ruang terbuka hijau (Dinas Pertamanan setempat pasti memiliki peta ini), atau lahan milik pribadi yang berkomitmen tinggi pada lingkungan akan lebih menjamin terpeliharanya pohon hingga daur hidupnya mencapai klimaks. Pilihan berikutnya adalah menanam di lahan yang berstatus "kritis" karena mengalami proses penggundulan.

Lahan konservasi-dengan berbagai status legalnya-merupakan pilihan yang sangat strategis untuk melakukan penanaman pohon. Sejak satu decade lalu, deforestasi semakin menghebat terjadi termasuk di kawasan-kawasan yang telah ditetapkan sebagai kawasan konservasi. Malahan, ada kecenderungan perusakan kawasan konservasi di berbagai tempat menjadi lebih cepat dibandingkan kawasan lainnya, karena pada periode sebelumnya kawasan konservasi relatif terjaga, sehingga kemudian tempat-tempat itu dianggap memiliki potensi kayu yang jauh lebih baik.

Hutan kota, termasuk kawasan konservasi yang ditetapkan oleh pemerintah dàerah juga merupakan tempat penanaman pohon yang tepat. Hutän kota adalah ruang terbuka yang ditumbuhi vegetasi berkayu di wilayah perkotaan. Hutan kota memberikan manfaat lingkungan sebesar-besarnya kepada penduduk pèrkotaan, dalam kegunaan-kegunaan proteksi, estetika, rekreasi dan kegunaan khusus lainnya (Djaiz dan Novian, 2000). Hutan kota merupakan bentuk persekutuan vegetasi pohon yang mampu menciptakan iklim mikro dan lokasinya di perkotaan atau dekat kota. Hutan di perkotaan ini tidak memungkinkan berada dalam areal yang luas. Bentuknya juga tidak harus dalam bentuk blok, akan tetapi hutan kota dapat dibangun pada berbagai penggunaan lahan. Oleh karena itu diperlukan kriteria untuk menetapkan bentuk dan luasan hutan kota. Kriteria penting yang dapat dipergunakan adalah kriteria lingkungan. Hal ini berkaitan dengan manfaat penting hutan kota berupa manfaat lingkungan yang terdiri atas konservasi mikroklimat, keindahan, serta konservasi flora dan kehidupan liar (Fandeli, 2004).

Dalam pelaksanaan pembangunan hutan kota dan pengembangannya, ditentukan berdasarkan pada objek yang akan dilindungi, hasil yang dicapai dan letak dari hutan kota tersebut. Berdasarkan letaknya; hutan kota dapat. dibagi menjadi lima kelas yaitu: 
1. Hutan Kota Pemukiman, yaitu hutan kota yang bertujuan membantu menciptakàn lingkungan yang nyaman dan menambah keindahan dan dapat menangkal pengaruh poluși kota terutama polusi udarà yang diakibatkan oleh adanya kendaraan bermotor yang terus meningkat dan lain sebagainya di wilayah pemukimain.

2. Hutan Kota Industri, berperan sebagai penangkal polutan limbah yang dihasilkan oleh kegiatan-kegiatan perindustrian, antara lain limbah padat, cair, maupun gas.

3. Hutan Kota Wisata/Rekreasi, berperan sebagai sarana untuk memenuhi kebutuhan rekreasi bagi masyarakat kota yang dilengkapi dengan sarana bermain, tempat peristirahatan, perlindungan dari polutan berupa gas, debu dan udara, serta merupakan tempat produksi oksigen.

4. Hutan Kota Konservasi, hutan kota ini mengandung arti penting untuk mencegah kerusakan, memberi pertindungan serta pelestarian terhadap objek tertentu, baik flora maupun faunanya di alaim. -

5. Hutan Kota Pusat Kegiatan, berperan meningkatkan-kenyamanan, keindahan, dan produksi oksigen di pusat kegiatan seperti pasar, terminal, perkantoran, pertokoan dan lain sebagainya. Di samping itu hutan kota juga berperan sebagai jalur hijaù di pinggir jalan yang berlalulintas padat (Irwan, 1997).

Secara umum bentuk hutan kota dapat berupa; jalur hijau, taman kota, kebun dan halaman, kebun hutan raya-binatang, dan hutan lindung.

Upaya ini bisa dilakukan dengan cara membangun hutan kota yang memiliki beranekaragam manfaat. Manfaat hutan kota salah satu diantaranya adalah sebagai penyerap Karbondioksida (CO2). Hutan merupakan penyerap gas karbon dioksida yang cukup penting, selain dari fito-plankton, ganggang dan rumput laut di samudera. Dengan berkurangnya kemampuan hutan dalam menyerap gas ini sebagai akibat menyusutnya luasan hutan akibat perladangan, pembalakan dan kebakaran, maka perlu dibangun hutan kota untuk membantu mengatasi penurunan. fungsi hutan tersebut. Selain itu, hutan kota dapat dibangun untuk mengelola lingkungan perkotaan untuk menurunkan suhu pada waktu siang hari dan sebaliknya pada malam hari dapat lebih hangat karena tajuk pohon dapat menahan radiasi balik (reradiasi) dari bumi.

\section{TEKNIK PELAKSANAAN CARBON ACCOUNTING}

Terkait dengan teknik pelaksanaan carbon accounting, setidaknya terdapat beberapa langkap yang harus dilalui. Berikut ini akan dijelaskan langkah-langkah tersebut.

Langkah 1.' Menentukan jumlah konsumsi sümber daya alam yang menghasilkan emisi karbon

Konsumsi sumber daya alam yang dapat menghasilkan emisi karbon mencakup pemakaian bahan bakar seperti jumlah liter premium, ton batu bara; 
m3 gas elpigi dan lain yang sejenisnya. Emisi karbon dapat dihitung dari data yang menggunakan salah satu bentuk bahan bakar, dengan asumsi bahwa jenis bahan bakar tersebut dikenal memiliki satu faktor emisi karbon. Bagian berikut ini menjelaskan bagaimana menghitung biaya bahan bakar yangy digunakan dalam berbagai kegiatan.

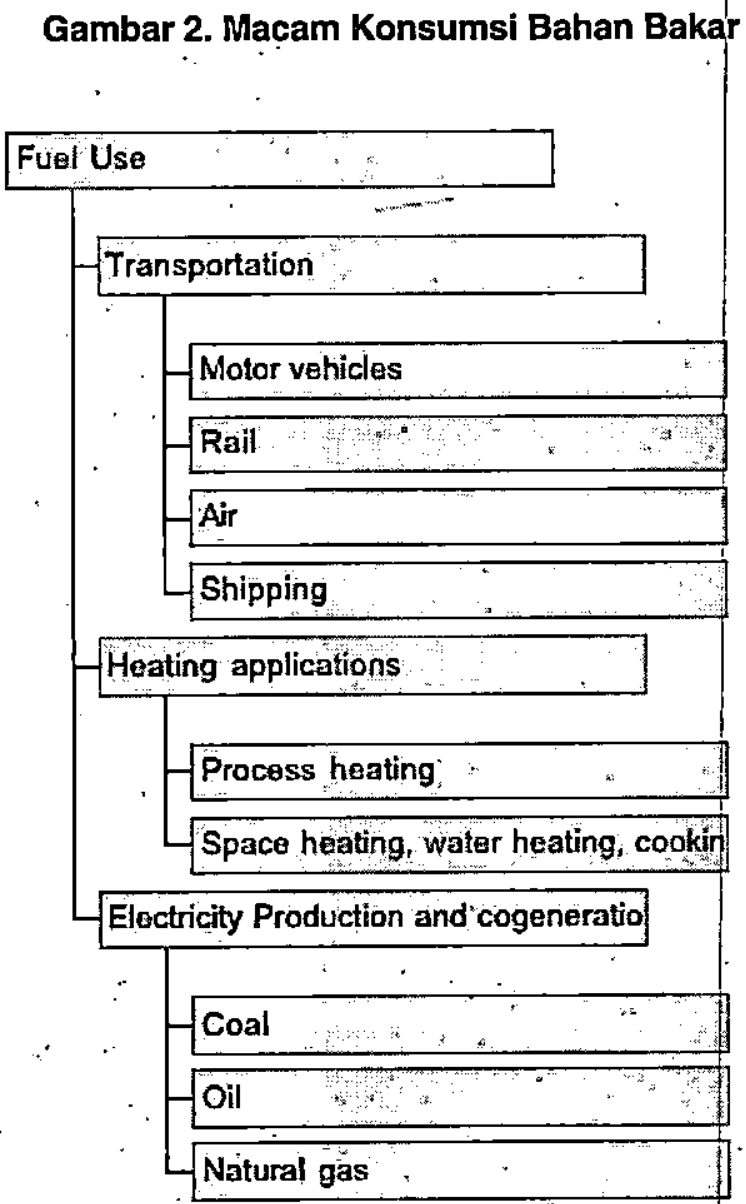

Dalam artikel ini hanya akan mengambil contoh perhitungan emisi katthem di bidang transportasi. Sebuah mobil digerakkan $10.000 \mathrm{mil}$ per tahum diam mendapat 25 mil per gallon, berapa banyak gallon bensin dari mobil tersthatt digunakan per tahun?

$$
10,000 \mathrm{mi} \cdot \frac{\mathrm{zul}}{25 m i}=400 \mathrm{gulllons}
$$




\section{Langkah 2. Menghitung emisi karbon dari pembakaran bahan bakar}

Semua bahan bakar-yang dikonsumsi akan menghasilkan emisi karbondioksida yang berbeda. Jumlati emitted per unit energi yang berasal dari bahan bakar tergantung pada jenis bahan bakkar: batu bara yang paling emits, gas alam yang paling rèndah. Emisi karbon dioksida dari pembakaran bahan bakar fosil tidak hanya tergantung pada jenis bahan bakar fosil yang digunakan, tetapi; tergantung pada besar keluasannya, pada sifat kimia dari bahan bakar tersebut. Dalam prakteknya, rata-rata rilai-nilai yang digunakan. Emisi karbon disebut faktor (CEFs), berhubungan dengan jumlah karbon emitted yang dihasilkan dari jumlah bahan bakar yang dikonsumsi.

$$
\begin{array}{ll}
\text { carbon released } & =\text { amount of fuel combusted } \times \text { CEF } \\
\text { dimana, } \mathrm{CEF} & =(\text { carbon emitted }) /(\text { amount of fuel combusted })
\end{array}
$$
bakar

Berikut ini disajikan data terkait dengan jumlah emisi masing-masing bahan

\begin{tabular}{|c|c|c|c|c|c|c|}
\hline \multicolumn{7}{|c|}{ Carbon Emissions Factors for Fossil Fuel Combustion } \\
\hline FUEL & $\begin{array}{c}\text { pounds } \mathrm{CO}_{2} \text { per } \\
\text { unit volume or } \\
\text { mass }\end{array}$ & $\begin{array}{l}\text { pounds } \mathrm{CO}_{2} \\
\text { permillion } \\
\text { Btu }\end{array}$ & $\begin{array}{c}\text { pounds } \\
\text { carbon per } \\
\text { million Btu }\end{array}$ & $\begin{array}{c}\text { million tonnes } \\
\text { carbon per } \\
\text { quad }\end{array}$ & $\begin{array}{c}\text { kilograms } \\
\text { carbon per } \\
\text { gigajoule }\end{array}$ & $\begin{array}{l}\text { kilograms } \mathrm{CO}_{2} \\
\text { per gigajoule }\end{array}$ \\
\hline \multirow{2}{*}{$\begin{array}{c}\text { Motor } \\
\text { Gasoline }\end{array}$} & 19.64 per gallon & 157.0 & 42.4 & 19.2 & 18.2 & 66.9 \\
\hline & 824.94 per bartrel & & & & & \\
\hline \multirow[t]{2}{*}{$\begin{array}{l}\text { Distillate } \\
\text { Fuel }\end{array}$} & 22.38 per gallon & $161.4^{*}$ & 43.6 & 19.8 & 18.7 & 68.8 \\
\hline & 940.11 per barrel & & & . & . & \\
\hline Methane & $\begin{array}{c}116.38 \text { per } 1000 \\
\text { cubic feet }\end{array}$ & 115.3 & 31.1 & 14.1 & 13.4 & 49.1 \\
\hline $\begin{array}{c}\text { Natural } \\
\text { Gas }\end{array}$ & $\begin{array}{c}120.59 \text { per cubic } \\
\text { feet }\end{array}$ & 117.1 & 31.6 & 14.3 & 13.6 & 49.9 \\
\hline Coal & 3723.95 per ton & 212.7 & 57.4 & 26.0 & 24.6 & 90.5 \\
\hline
\end{tabular}

\section{Tabel 5}

Langkah 3. Menghitung daerah tanah yang diperlukan untuk menyerap emisi karbon

Carbon footprinting menghitung biocapacity (global hektar) yang diperlukan untuk menyerap seluruh emitted karbon dioksida dari pembakaran bahan bakar. Tahap ini tidak saja focus pada berapa hektar tanah yang harus dipersiapkan. untuk menyerap emisi karbon yang telah dihitung tetapi juga fokus pada 
Joko Susilo: Penerapan Carbon Offset Policysebagai Bagian dari CSRPerusahaan ...

keberadaan hutan kota, konservasi hutan lindung, sampai pada kebijakan carbori offset untuk perusahaan berupa penanaman pohon sebagai konsekuensi atas emisi karbon yang dikeluarkannya. Artikel ini tidak membahas secara detail bagaimana cara menghitung luasan tanah ataupun banyaknya pohon yang harus ditanam. Banyak software ataupun kalkulator yang biasa dikenal dengan carbon cost accounting software ataupun carbon calculator yang memudahkan pengguna untuk menghitung berapa emisi karbon yang dihasilkan.

Adapun untuk siklus akuntansi dari carbon accounting dapat dilihat dalam bagan berikut ini.

\section{Gambar 3. Aliran Siklus Akuntansi Carbon Accounting}

1 Carbon consumption workflow

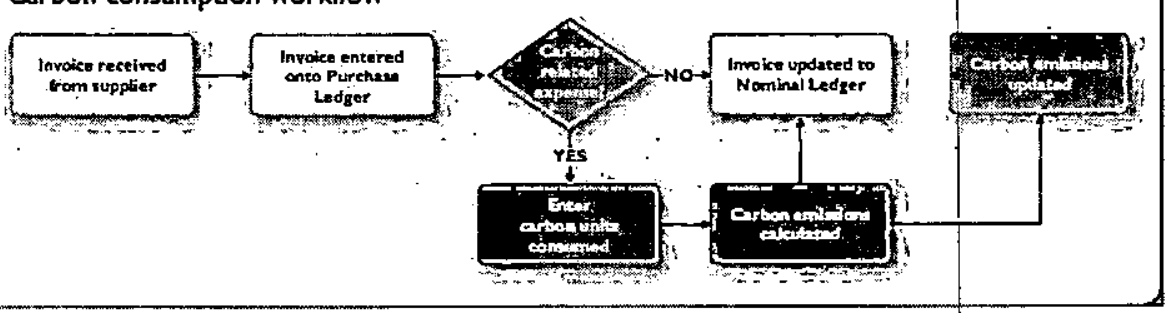

Dari bagan tersebut dapat dijelaskan bagaimana proses siklus akuntansi dalam carbon accounting mencakup diterbitkannya bukti transaksi sebagai akibat dari langkah satu di atas. Kemudian, diinput ke dalam sistem pengolahan akuntansi yakni jurnal. Dalam tahap ini, selanjutnya dianalisa apakah transaksi ini terkait dengan konsumsi karbon, jika terkait maka diinput pula ke dalam modul unit konsumsi karbon. Dalam modul ini kemudian akan dihitung jumlah emisi karbon yang dihasilkan untuk di-update.

Pemanasan global adalah merupakan isu semua pihak. Masing-masing pihak bertanggung jawab sesuai dengan kapasitasnya. Akuntansi sebagai ilmu terapan yang tidak bebas nilai, sangat dipengaruhi oleh isu pemanasan global ini. Akibatnya, muncul kepedulian dalam lingkup ini seperti munculnya green accounting, akuntansi lingkungan, akuntansi keanekaragaman hayati, akuntansi hutan sampai dengan munculnya akuntansi karbon. Carbon accounting ini mengukur total emisi gas rumah kaca yang disebabkan secara langsung dan tidak langsung oleh seorang individu, aktivitas, organisasi atau produk. Penilaian karbon dan pelaporannya ini dapat membantu organisasi mengadopsi strategi yang bertujuan untuk mengatasi perubahan iklim.

Penanaman pohọ, baik itu di lingkungan individu, masyarakat, perusahaan, maupun perkotaan, merupakan wujud kongkret adanya tanggung jawab lingkungan pihak tersebut. Terkhusus untuk perusahaan, maka kebijakan penanaman pohon ini merupakan kebijakan carbon offset sebagaji konsekuensi 
atas emisi karbon yang dilepaskannya. Untuk membantu memudahkan perusahaan dalam menghitung berapa emisi karbon yang dihasilkan dan berapa konsekuensi kebijakan carbon offset yang dikeluarkan, maka dibutuhkanlah carbon accounting system. Di Indonesia, penerapan akuntansi karbon masih sebatas wacana: Untuk itu diperlukan perhatian dari semua pihak, khususnya akuntan-akuntan Indonesia untuk segera merealisasikan wacana carbon accounting ini menjadi teknologi yang dapat dengan mudah dijalankan di indonesia ini.

\section{DAFTAR PUSTAKA}

Ball, Amanda. (2005). "Environmental; accounting and change in UK local government". Accounting, Auditing \& Accountability Joumal. Vol. 18, No. , pp. 46-373.

Bebbington, Jan: (1997). "Engagement, education, and sustainability". ACcounting, Auditing \& Accountability Journal. Volume 10. No 3., pp. 365-381.

Belkaoui, Ahmed Riahi dan Ronald D. Picur, (1991). "Cultural determinism and the perception of accounting concepts," The International Joumal of Accounting.,26: 118-130.

Bragdon, $P_{\text {, }}$ dan B. Donavan. (1990). 'Voters' concerns are tuming the political agenda green". Congressional Quarterly (January 20): 186-187.

Cooper, C. (1992), "The non and nom of accounting for (m)other nature", Accounting, Auditing \& Accountability Journal, Vol. 5 No. 3, pp. 1639.

Choi, Jong-Seo. (1999) "An investigation of the initial voluntary environmental disclosures made in Korean semi-annual financial report". Pacific Accounting Review. Paimerșton North, June, Vol. 11, Iss. 1; pp. 73.

Gamble, G.O et al. (1995). "Environmental disclosures in annual reports and 10Ks: An Examination". Accounting Horizons. Sarasota, September. Vol. 9. Iss. 3, pp. 34.

Global Reporting Initiative. (2000). Sustainable Reporting Guidenlines on Economic, Environmental and Sosial Performance, GRI, Boston, MA.

Gray, R. dan Laughlin, R. (1991), "Editorial", Accounting, Auditing \& Accountability Journal, Vol. 4 No. 3, pp. 1-4.

Gray, R.H. (1992). "Accounting and environmentalism: an exploration of the challenge of gently accounting for accountability, transparency and sustainability". Accounting, Organizations and Society, Vol. 17 No. 5 , pp. 399-425. 
Gray, R., R. Kouhy dan S. Lavers (1995). "Corporate Sosial and Environmental Reporting: A Review of the Literature and a Longitudinal Study . of UK Disclosure". Accounting, Auditing \& Accountability Journal, Vol. 8, 47-77.

Gray, R. H., Owen, D.L. dan Maunders, K.T. (1998), "Corporate Sosial Reporting: Emerging Trends in Accountability and The Sosial Contract". Accounting, Auditing \& Accountability Journal, Vol. 9 No. 1, pp. 77108.

Jalal. (2007). "Penanaman Pohon sebagai Bentuk CSR yang paling Penting". Seminar Dinas Pertamanan-Jakarta. www.csrindonesia.com

Maunders, K.T. dan Burritt, R. (1991), "Accounting and ecological crisis", Accounting, Auditing \& Accountability Journal, Vol. 4 No. 3, pp. 9-26.

Milne, M.J. (1991), "Accounting, environmental resource values, and nonmarket valuation techniques for environmental resources: A review", Accounting, Auditing \& Accountability Journal, Vol. 4 No. 3, pp. 81109.

Rubinstein, D. (1989). "Black oil, red Ink". CA Magazine, November, pp. 3035.

Rubinstein, D. (1991). "Lesson of Love", CA Magazine, Maret, pp. 35-41.

Rubinstein, D. (1992). "Bridging the Gap between Green Accounting and Black Ink", Accounting Organization and Society, Vol. 17 No, 55, pp. 501-508.

Tilt, Carol Ann. (2001). "The content and disclosure of Australia corporate environmental policies". Accounting, Auditing \& Accountability Journal, Vol. 14 lss. 2, pp. 190.

Tinambunan, Riswadi S. (2007). Tesis. www.damandiri.com

Utomo, M. M. (2001). "Wacana Akuntansi Alternatif". Ak̈samala institute. Februari.

Watts; RL. dan J.L.Zimmerman (1978). "Towards a Positive Theory of the Determination of Accounting Standards". The Accounting Review, 53,112-134.

WWF-Indonesia. (2008). "Deforestasi, Degradasi Hutan, Hilangnya Keanekaragaman Hayati dan Emisi CO2 di Riau, Sumatera, Indonesia". Laporan Teknik WWF-Indonesia. Situs www.wwf or.id

Hittp://www.eldorado.com/pg newsletter read-128.html 